\title{
Gerhard Storch - a legend in mammal research (II)
}

(In memory of Gerhard Storch)

With the special issue in memory of Dr. Gerhard Storch, we wanted to recognise the impact that his research had in the fields of mammalogy and palaeomammalogy. As so many colleagues responded positively to our initiative, a second volume was required to gather all articles written in his honor.

In the introduction of volume I, we covered the professional achievements of Gerhard Storch. But we also pointed out what an outstanding personality he was, generous and with a great sense of humor. Here, we want to give a glimpse into his life from another, more personal perspective, thanks to his former research assistants (Angelika Helfricht and Katrin Krohmann) and his daughter (Anne Storch).

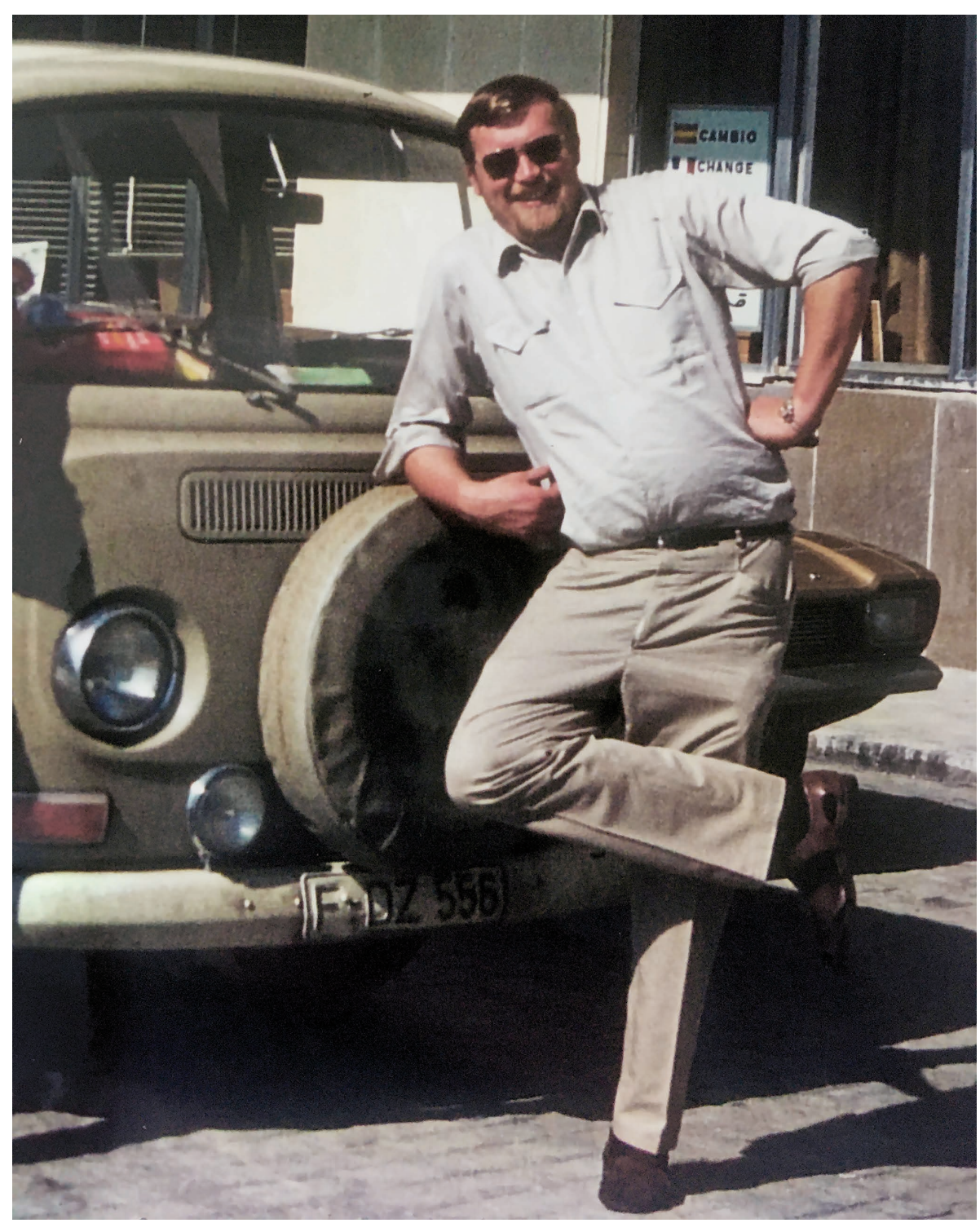

Text-fig. 1. Gerhard Storch standing in front of a Senckenberg off-road vehicle on the way to field work (1970s). Photo J.-L. Franzen.

\section{Traveling with my father}

(by Anne Storch)

Certain paths and routes cannot be covered without becoming time travel. The long drive over the Brenner motorway, the road from Oppenheim to Guntersblum, the curves on Monte Baldo - they are always accompanied by vivid memories of my father. Not because we experienced or at least saw something special there (that too), but because all these landscapes and paths are filled with his stories. There, he remains fully present and his voice is still lingering. He was indeed very good in storytelling, in narrating something in general, and always yielded the best effects by sounding as casual as possible.

This casualness, combined with a kind of somewhat particular knowledge and a fine Hessian accent elicited a constant demand for more, and so he had to tell many of his tales again and again. There was the morbid story of construction worker, who got into one of the huge pillars of the Europa Bridge, which got more and more detailed with each trip - the arm that still 


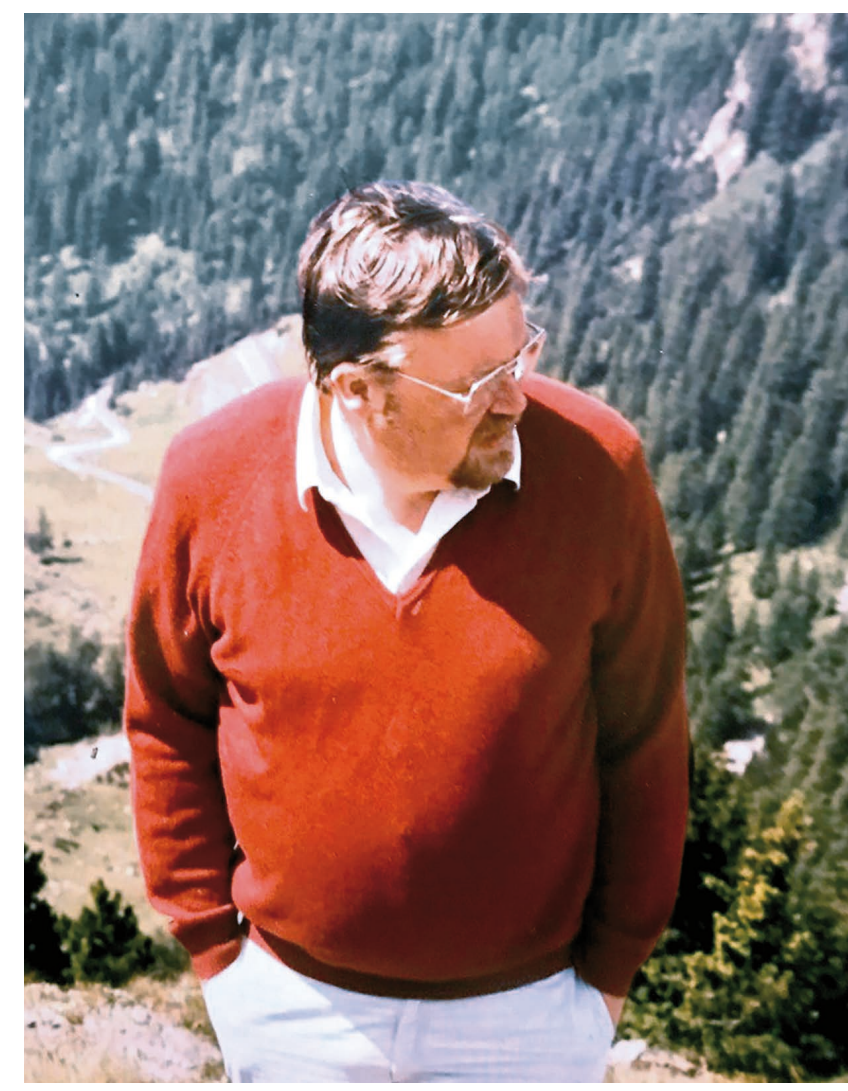

Text-fig. 2. Always on the lookout for wildlife: Gerhard Storch on family vacation in Italy (1980s). Photo K. Storch. waved, last words sounding out of the concrete. Other stories were no less particular, but they were true and provided much wisdom for later times: Stories about how to catch bats by fishing them from the hotel balcony in the evening, and how the lid of the large alcohol container in which they had to be put afterwards never really closed; about unbelievably short hikes and that walking uphill for even a minor distance is usually not worthwhile anyway; about how a certain beetle in a matchbox can make one stay awake all night; that ice cream without raspberry sauce is potentially dreary; that one shouldn't try too hard to fit in.

He loved to travel for a very long time and was able to suffer from great wanderlust. He also liked being at home. He shied away from all bourgeois forms of socializing. He listened to the radio on the car for as long as there were good jazz shows, and when that stopped he kept on listening to his records, especially on Saturdays. Every now and then we would meet in the now closed record store at Frankfurt's Hauptwache, where he usually took his time to search for new records.

He knew so much about what certain places once used to look like, what animals had lived there and what people had done there that I can still imagine these things today, although almost all the fields in which we used to walk have long since been turned into sad industrial edgelands. An old photo album that he must have begun as a child shows some of these places and what one could have found there if one only watched closely enough - sundew, a black grass snake, garlic toads.

\section{Research is better with a good cup of coffee}

(based on interviews with Angelika Helfricht and Katrin Krohmann)

The year 1967 was an important one for the 28-year-old Gerhard Storch, as in the same year he finished his $\mathrm{PhD}$ and got married. At this time, he was working in the Senckenberg Mammalogy Section of Heinz Felten (1922-2000), where a young trainee, Angelika Helfricht, was learning to become a technical assistant in natural history museums. A. Helfricht followed the beginning of Gerhard's independent career, when he skillfully obtained a position of research assistant at Senckenberg through a grant from the Deutsche Forschungsgemeinschaft (DFG) that supported his own position. During that time, Gerhard also oversaw some of the reorganization of the mammal exhibition at the Senckenberg Naturmuseum Frankfurt, and slowly became inevitable at the institute. And so, it came that in 1969, with the backing of Felten, Gerhard Storch became the head of the newly established Section Mammalogy II. His newly appointed technical assistant was none other than A. Helfricht. They would work together for their whole career.

In the early days of the new section, the working atmosphere was like in a family, and there were even some daily rituals. For instance, a full coffeepot was made first thing in the morning, and a second was usually necessary until the finishing time: Gerhard was a heavy coffee drinker. After lunchbreak, it was not unusual for him to play a game of ping-pong in the collection room. Storch was from a new generation of scientists, more amenable to hobby palaeontologists (giving him access to unpublished material), and to technicians. Yet, although they worked together for 35 years, and by common agreement, the very polite Gerhard Storch would never be on first name terms with Angelika Helfricht. This tradition was perpetuated with Katrin Krohmann, his second technical assistant (starting in 1999), and only switched to the unformal "you" after his retirement. His courtesy and the fact that he was very self-critical, and could laugh about himself, would gain him the respect of his staff.

Gerhard, like many scientists of his generation, had a hard time catching up with computer technology. Yet, he was very enthusiastic about technological improvements in the field, and would use modern methods, when they proved useful. For instance, he increasingly replaced drawings of fossil teeth by scanning electron microscope (SEM) images. Likewise, he improved the description of the Messel fossils thanks to the rising X-ray imaging methods. He welcomed the possibilities opened up by the new techniques, but was not interested in actually operating the computer. Therefore, all image processing/ editing were done by collaborators, and, until his last years at Senckenberg, even his letters and manuscripts were typewritten by his assistants. He actually enjoyed their help and tended all the more to entrust them with tasks that significantly supported his research. "Machen Sie mal!" [Take care of it!] was his usual way to send his assistants working on collection specimens. He trained, supported and encouraged them to take over tasks like identification and sorting of the thousands of micromammals remains in the collection. Not only did this allow his assistants to be autonomous in their work, but it also put them in a position to perform reliable preparatory work that would represent an invaluable gain of time for his research.

The new Section Mammalogy II was focused on fossil mammals. Although Storch was not academically trained in the field of palaeontology, the search for the origin of and explanation for the current distribution of extant taxa, always interested him 
eagerly, and he was always on the lookout for fossils up from his earliest field studies. This curiosity for so many aspects of biology is pervasive in Gerhard's career and might have its roots in the hunting expeditions with his father. Hence, from the 1970s onwards, Gerhard's field studies with mousetraps turned into palaeontological excavations... with mousetraps (!), as he never went out, even during family vacation, without taking some traps along with him. As the new section needed a collection, it was decided that the fossil small mammals (or micromammals) housed so far within the Fossil Vertebrate Collection were to be separated and curated by Storch. Soon, this small smorgasbord of fossil mammals grew into a rich, well-organized working collection with focus on Neogene (and later also Paleogene) small mammals. Many were collected directly by Storch and his assistant, often after long and tedious hours of wet sieving on site and at the lab. Fossils from German sites, like Dorn Dürkheim (Upper Miocene; Pleistocene), but also from the Mediterranean Region (e.g., Pleistocene of Malta, Chios, Kalymnos) are well represented.

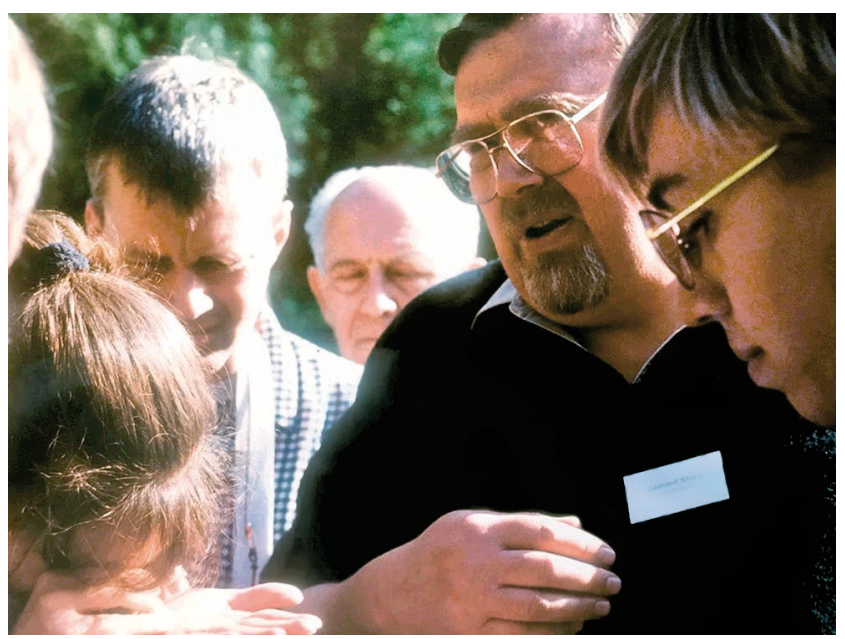

Text-fig. 3. Gerhard Storch sharing his knowledge about small mammals on a field trip during a conference in Kraków (Poland), 1994. Photo K. Storch. But Storch had also the brilliant idea to gather together in his collection casts of specimens from across the world. Thanks to his open-mindedness and disregarding political barriers, he developed a large network of collaborations with international researchers (from USA, France, Netherlands, Poland, the former GDR, former Czechoslovakia, to Mongolia and China). In exchange for casts of his material, he would receive casts of some important (often type) material. Helfricht was pivotal in this, as she became trained in the difficult art of casting micromammals (often isolated teeth). As a result, the Fossil Small Mammal Collection is a fantastic resource for anatomical comparison. Gerhard maintained personal contact with international researchers, in a very good English, yet with a unique local "Hassian" accent that made any talk even more sympathetic. Many research projects would flourish out of these contacts (e.g., in Mongolia and China). When Felten retired, Storch took over the Recent Mammal Collection and had now two collections to curate. This was facilitated however, thanks to the hard work of A. Helfricht on the Fossil Small Mammal Collection, as well as the independent management of the Recent Mammal Collection by O. Lütt (replaced by K. Krohmann after he retired), the technical assistant of Felten since the early days of Storch in the Mammalogy Section. The Recent Mammal Collection is still curated by the Section Mammalogy, but since 2018, the Fossil Small Mammal Collection, painstakingly developed by Storch, is again curated separately, now in the Section Palaeomammalogy.

Fieldwork was an important part of Gerhard's career, and he often went with other colleagues and with his assistant. His collaboration with Senckenberg colleague J. L. Franzen started with such fieldwork, at Dorn Dürkheim (Upper Miocene and Pleistocene; Germany). Both researchers being mammal specialists, they shared among themselves the fossil material they excavated: "large mammals" for Franzen and "small mammals" for Storch. This collaboration was continued at the Messel Pit Fossil Site (Middle Eocene; Germany). There, both researchers had to face the difficulties, but also stimulation, of trying to save as many fossils as possible before the site was turned into a landfill (which was eventually precluded, in great part thanks to the palaeontological discoveries and publications of Franzen and Storch). During the hard labour at Messel, Gerhard's humour was a regular feature. Like in this instance, when a large fossil crocodile was carried out of the pit, up the steep slope, and he dubbed the procession: "Kroko-mobile".

Moreover, Storch particularly enjoyed fieldworks, because they always uncovered something new that would spark his interest. Most of his work was curiosity driven research, which he wished to pursue without unsolicited distraction. Accordingly, Gerhard did not particularly enjoy public outreach, like press or TV interviews. Krohmann remembers how irritated he was when a journalist asked him during an interview to "take the fossil out of the drawer again, but this time with more action". Such strict focus on his research also explains why Storch was not more involved in teaching. Yet, he liked to enlighten young researchers and even participated in the supervision of PhD students. As he became head of the Terrestrial Zoology Department, and at the same time chair of the Senckenberg Scientific Committee, he would often grumble about how these administrative tasks kept him away from doing research.

Gerhard Storch was therefore looking forward to his retirement, and regularly told how the end of his administrative duties would give him back time for doing research. He did so at first, and came frequently to the institute until 2009. Then, a series of health problems prevented him from coming in, but he kept contact by phone with Krohmann: "Die Sektion muss laufen!" [The Section must go on!] as he used to say. Gerhard Storch died on August 11 ${ }^{\text {th }}, 2017$ at the age of 78, and with him, a whole generation of palaeontologists seems to have passed on the baton. Indeed, not long after Gerhard, his friends and collaborators Bernard Sigé (France), Jens Lorenz Franzen and Dieter Kock (Germany), as well as Gregg Gunnell (USA) passed away. Their work and achievement will benefit our and the next generations of researchers, as, paraphrasing the words of Sir Isaac Newton: "We stand on the shoulders of the giants that came before us." 